University of South Florida

DIGITAL COMMONS

Digital Commons @ University of

@ UNIVERSITY OF SOUTH FLORIDA

South Florida

\title{
Sedimentation Patterns in a Stabilized Migratory Inlet, Blind Pass, Florida
}

Ping Wang

Department of Geology, University of South Florida, pwang@usf.edu

David K. Tidwell

University of South Florida

Tanya Beck

University of South Florida, tbeck1@usf.edu

Nicholas C. Kraus

USAE Research and Development Center

Follow this and additional works at: https://digitalcommons.usf.edu/gly_facpub

Part of the Geology Commons

\section{Scholar Commons Citation}

Wang, Ping; Tidwell, David K.; Beck, Tanya; and Kraus, Nicholas C., "Sedimentation Patterns in a Stabilized Migratory Inlet, Blind Pass, Florida" (2007). Geology Faculty Publications. 223.

https://digitalcommons.usf.edu/gly_facpub/223

This Conference Proceeding is brought to you for free and open access by the Geology at Digital Commons @ University of South Florida. It has been accepted for inclusion in Geology Faculty Publications by an authorized administrator of Digital Commons @ University of South Florida. For more information, please contact digitalcommons@usf.edu. 
Wang, P., Tidwell, D. K., Beck, T. M., and Kraus, N. C. 2007. Sedimentation Patterns in a Stabilized Migratory Inlet, Blind Pass, FL. Proceedings Coastal Sediments '07 Conference, ASCE Press, Reston, VA, 1377-1390.

\title{
SEDIMENTATION PATTERNS IN A STABILIZED MIGRATORY INLET, BLIND PASS, FLORIDA
}

\author{
Ping Wang ${ }^{1}$, David K. Tidwell ${ }^{1}$, Tanya M. Beck ${ }^{1}$, Nicholas C. Kraus ${ }^{2}$ \\ 1. Department of Geology, University of South Florida, 4202 E. Fowler Ave., Tampa, \\ FL 33620, USA. pwang@cas.usf.edu \\ 2. U.S. Army Engineer Research and Development Center, Coastal and Hydraulics \\ Laboratory, 3909 Halls Ferry Road, Vicksburg, MS 39180-6199, USA. \\ Nicholas.C.Kraus@erdc.usace.army.mil.
}

\begin{abstract}
The shoaling rate in Blind Pass entrance channel approximately equals the net southward longshore sediment transport rate. Most of the shoaling occurs along the northern side of the channel. Flow measurements and numerical modeling reveal that the ebb current is approximately twice as strong in the thalweg along the south side as compared to the rest of the channel. In contrast, the flood current is mainly uniform across the inlet and is stronger than the ebb flow over the northern portion. This flow-velocity distribution induced by a nearly 90-deg bend of the channel contributes to the shoaling pattern. Two years after the 2000 dredging, the shoal along the north side became shallow enough to induce wave breaking. Distinctive shoaling patterns influenced by seasonal wave climate were observed. Sediment deposition in the channel is closely related to the passages of cold fronts, which significantly increases the sediment supply by longshore transport.
\end{abstract}

\section{INTRODUCTION}

Tidal inlets are links between the coastal ocean and back-barrier bays, exchanging water, sediments, nutrients, and pollutants between them. Many inlets also serve as navigation channels. Because tidal inlets interrupt the continuity of shore processes, they often influence the sediment budgets and can cause beach erosion. Dean (1988) concluded that more than $80 \%$ of the erosion along the Florida coast can be directly linked to tidal inlets. Maintaining stable and deep navigation channels and also allowing for adequate sand bypassing provides a major challenge to coastal engineering. Understanding the processes that control shoaling at inlet channels is, therefore, an important challenge. 


\section{Report Documentation Page}

Public reporting burden for the collection of information is estimated to average 1 hour per response, including the time for reviewing instructions, searching existing data sources, gathering and maintaining the data needed, and completing and reviewing the collection of information. Send comments regarding this burden estimate or any other aspect of this collection of information, including suggestions for reducing this burden, to Washington Headquarters Services, Directorate for Information Operations and Reports, 1215 Jefferson Davis Highway, Suite 1204, Arlington VA 22202-4302. Respondents should be aware that notwithstanding any other provision of law, no person shall be subject to a penalty for failing to comply with a collection of information if it does not display a currently valid OMB control number.

\begin{tabular}{|c|c|c|}
\hline $\begin{array}{l}\text { 1. REPORT DATE } \\
\mathbf{2 0 0 7}\end{array}$ & 2. REPORT TYPE & $\begin{array}{l}\text { 3. DATES COVERED } \\
\mathbf{0 0 - 0 0 - 2 0 0 7} \text { to 00-00-2007 }\end{array}$ \\
\hline \multirow{3}{*}{\multicolumn{2}{|c|}{$\begin{array}{l}\text { Sedimentation Patterns in a Stabilized Migratory Inlet, Blind Pass, } \\
\text { Florida }\end{array}$}} & 5a. CONTRACT NUMBER \\
\hline & & 5b. GRANT NUMBER \\
\hline & & 5c. PROGRAM ELEMENT NUMBER \\
\hline \multirow{3}{*}{\multicolumn{2}{|c|}{ 6. AUTHOR(S) }} & 5d. PROJECT NUMBER \\
\hline & & 5e. TASK NUMBER \\
\hline & & 5f. WORK UNIT NUMBER \\
\hline \multicolumn{2}{|c|}{$\begin{array}{l}\text { 7. PERFORMING ORGANIZATION NAME(S) AND ADDRESS(ES) } \\
\text { U.S. Army Engineer Research and Development Center,Coastal and } \\
\text { Hydraulics Laboratory,3909 Halls Ferry Road,Vicksburg,MS,39180-6199 }\end{array}$} & $\begin{array}{l}\text { 8. PERFORMING ORGANIZATION } \\
\text { REPORT NUMBER }\end{array}$ \\
\hline \multirow{2}{*}{\multicolumn{2}{|c|}{ 9. SPONSORING/MONITORING AGENCY NAME(S) AND ADDRESS(ES) }} & 10. SPONSOR/MONITOR'S ACRONYM(S) \\
\hline & & $\begin{array}{l}\text { 11. SPONSOR/MONITOR'S REPORT } \\
\text { NUMBER(S) }\end{array}$ \\
\hline
\end{tabular}

12. DISTRIBUTION/AVAILABILITY STATEMENT

Approved for public release; distribution unlimited

13. SUPPLEMENTARY NOTES

Proceedings Coastal Sediments '07 Conference, 13-17 May 2007, New Orleans, LA, ASCE Press, 1377-1390

14. ABSTRACT

The shoaling rate in Blind Pass entrance channel approximately equals the net southward longshore sediment transport rate. Most of the shoaling occurs along the northern side of the channel. Flow measurements and numerical modeling reveal that the ebb current is approximately twice as strong in the thalweg along the south side as compared to the rest of the channel. In contrast, the flood current is mainly uniform across the inlet and is stronger than the ebb flow over the northern portion. This flow-velocity distribution induced by a nearly 90-deg bend of the channel contributes to the shoaling pattern. Two years after the 2000 dredging, the shoal along the north side became shallow enough to induce wave breaking. Distinctive shoaling patterns influenced by seasonal wave climate were observed. Sediment deposition in the channel is closely related to the passages of cold fronts, which significantly increases the sediment supply by longshore transport.

15. SUBJECT TERMS

16. SECURITY CLASSIFICATION OF:

a. REPORT unclassified b. ABSTRACT unclassified c. THIS PAGE unclassified
17. LIMITATION OF ABSTRACT Same as Report (SAR)
18. NUMBER 19a. NAME OF OF PAGES RESPONSIBLE PERSON

14 
Blind Pass, a small stabilized migratory inlet, provides an excellent case for the study of inlet shoaling and interactions with adjacent beaches.

Blind Pass and the adjacent Johns Pass service a portion of Boca Ciega Bay along the west-central Florida coast (Fig. 1). The entire area, from the beach to the inlets to the back-bay, is heavily developed. The origin of Blind Pass is not clear. Before the opening of Johns Pass by a hurricane in 1848, Blind Pass was a major inlet along this stretch of the coast with large flood and ebb shoals. As Johns Pass captured a substantial portion of the tidal prism, Blind Pass became a wave-dominated inlet and started rapid southward migration. It was eventually stabilized with a series of hard structures. Following the stabilization, chronic shoaling of the channel and subsequent dredging occurred, along with a persistent erosion problem at the downdrift Upham Beach.

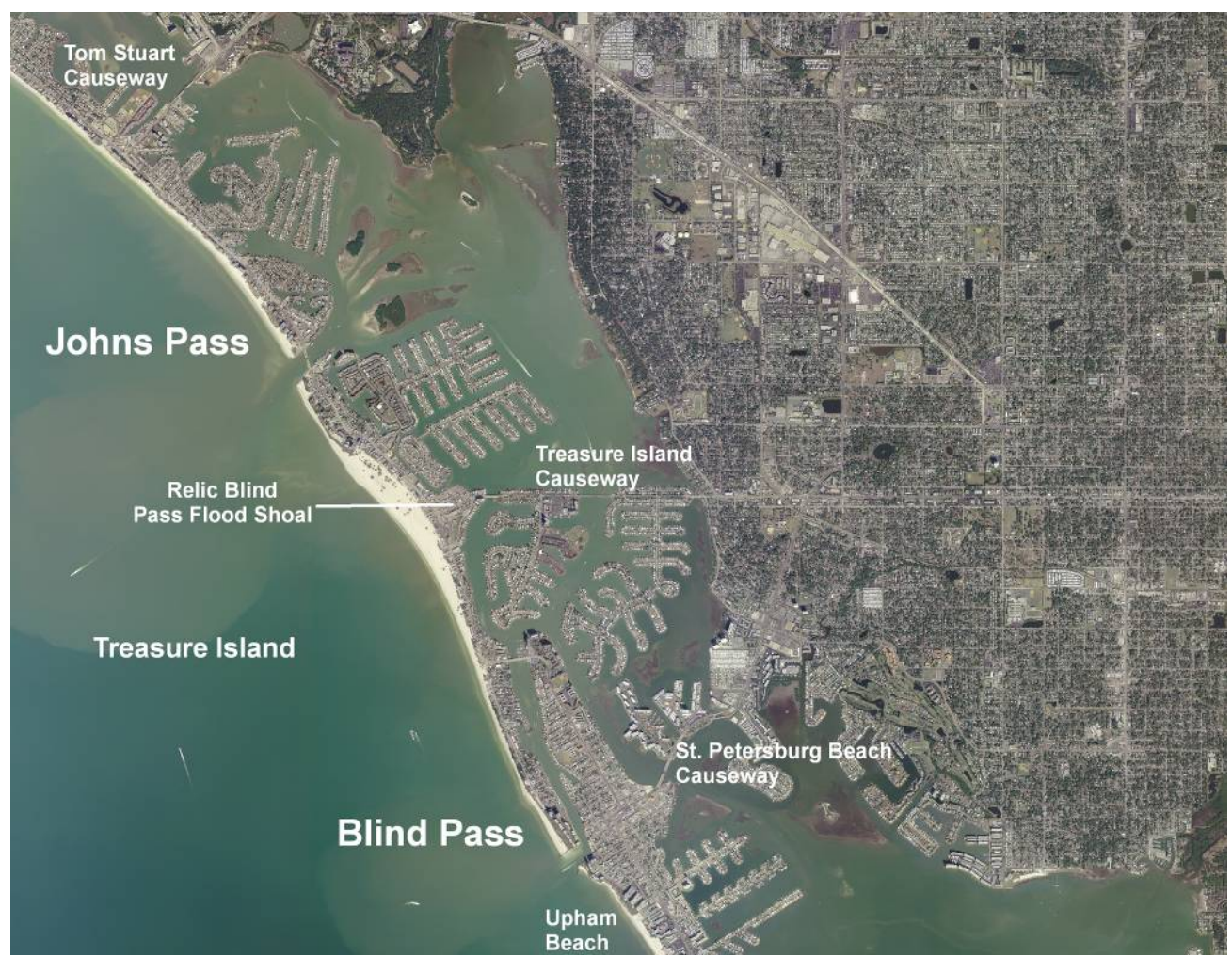

Fig. 1. Blind Pass and Johns Pass to the north.

This study quantifies the channel shoaling and associated processes following the last dredging in 2000. Time-series bathymetry surveys and flow measurements were conducted along with circulation modeling of the Blind Pass and Johns Pass system. The overall goals of this study are to understand the rate and processes of shoaling in the inlet channel and its interaction with adjacent beaches. Specific objectives include: 1) quantifying the shoaling and scouring pattern in the inlet channel, 2) investigating wave conditions and tidal flow velocities, particularly in relation to the inlet morphology change, and 3) determining the relationship between morphology change and the driving forces. 


\section{HISTORICAL EVOLUTION AND ENGINEERING AT BLIND PASS}

Blind Pass is one of the most artificially modified inlets along the west-central Florida coast (Davis and Barnard 2000). Most of the engineering efforts are aimed at halting lateral inlet migration and reducing shoaling in the inlet entrance channel. The jetties have successfully stopped the longshore migration; however, channel shoaling has continued, and severe and persistent downdrift erosion was induced. The inlet needs to be dredged periodically and the sand used to nourish the adjacent beaches, especially Upham Beach, located directly to the south and downdrift.

Before 1848, Blind Pass was a fairly large inlet and was located directly gulfward of its flood shoal (Fig. 1). The opening of Johns Pass that year started a substantial trend of decreasing tidal prism at Blind Pass. As a result, the inlet began to migrate rapidly to the south so that, by 1926, the inlet had migrated more than $2 \mathrm{~km}$. The year 1937 marks the beginning of direct stabilization with initial dredging and construction of the south jetty and seawall. Continued sediment shoaling in the inlet entrance channel led to extension of south jetty in 1951 and construction of the north jetty in 1962. Also, between 1940s and 1960s, extensive dredge-and-fill construction was conducted in Boca Ciega Bay (Fig. 1). The artificially created land, as well as construction of several causeways, resulted in significant reduction of back-bay area, and thus a further decrease in tidal prism. The south jetty was extended in 1975, and a weir with a 12-m gap was added in 1986. The weir was closed in 2004. The north jetty was extended in 1976 and 1983. These structures along with the significantly decreased tidal prism have made Blind Pass channel a trap of the southward longshore transport allowing little to no bypassing. In order to maintain the channel, the inlet was dredged in 1937, 1964, 1969, 1975, 1979, 1983, 1990, and 2000.

Artificial interferences on the morphodynamics of Blind Pass are illustrated well by time-series aerial photographs (Fig. 2). Blind Pass is characterized by a nearly 90-deg. turn before entering the Gulf of Mexico. We focus on the entrance channel at and gulfward of the turn. In 1926 (Fig. 2A), the inlet was still in pristine condition. A large ebb shoal and southward sand bypassing are apparent. By 1942 (Fig. 2B), the south side had been stabilized. The ebb delta and southward bypassing are still visible, but to a reduced degree. Beach erosion at Treasure Island to the north becomes obvious. By 1957 (Fig. 2C), the ebb shoal and southward bypassing are still visible. At the same time, erosion at the updrift Treasure Island had become severe. By 1969 (Fig. 2D), both sides of the inlet were stabilized. The ebb shoal and southward bypassing diminished substantially. Through a combination of jetty, groin field, and beach nourishment, erosion at the updrift Treasure Island was mitigated. However, severe erosion at downdrift Upham Beach to the south developed. Shoaling of the inlet channel and severe erosion downdrift are the main features of the 1984 photo (Fig. 2E), which was taken a year after the 1983 dredging. The ebb shoal and southward bypassing become indistinguishable. This trend continued and is shown in the 2000 photograph (Fig. 2F) just before the last dredging to date. The present study on shoaling in the channel was commenced after the 2000 dredging. 


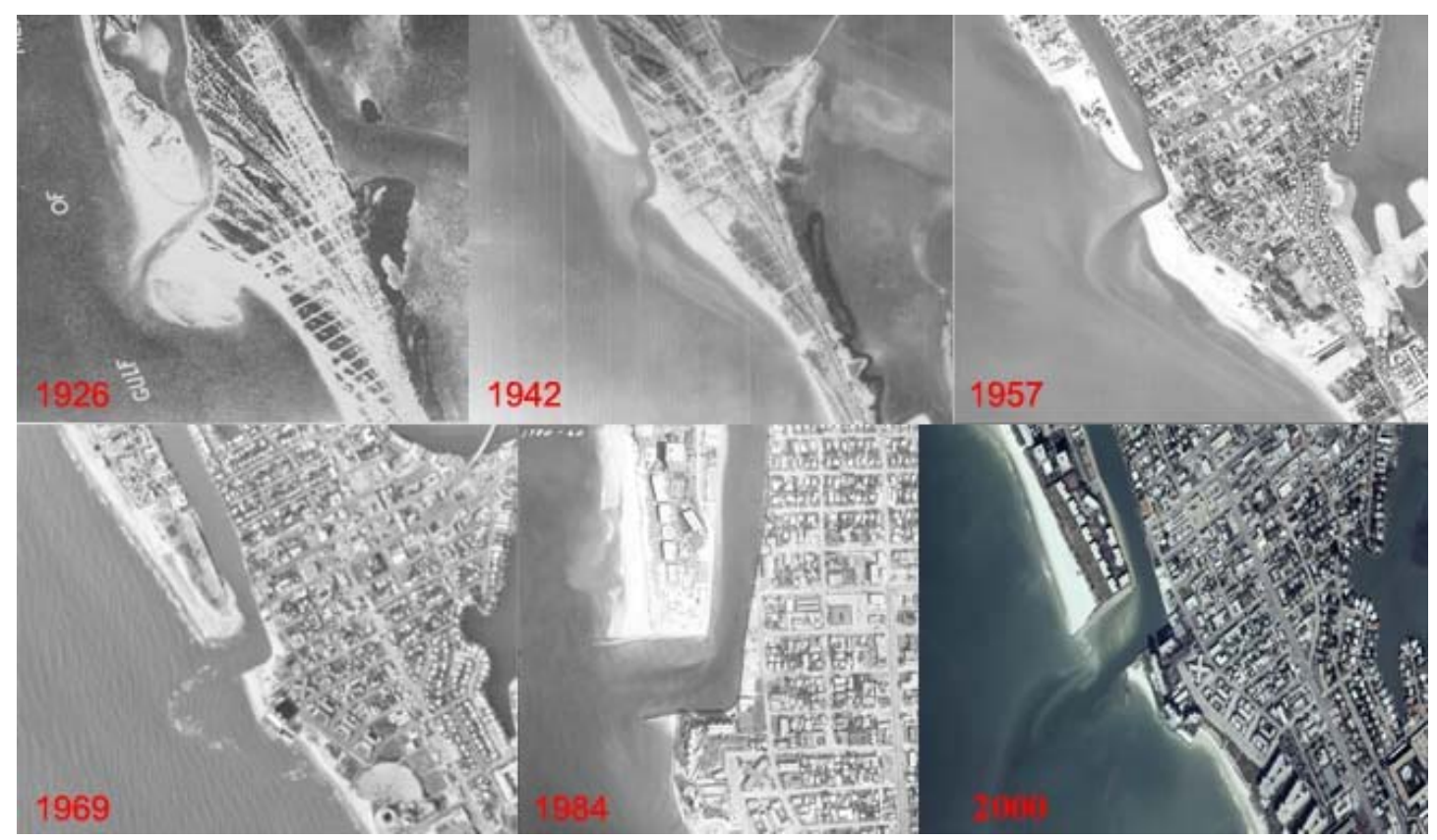

Fig. 2. Time-series aerial photos of Blind Pass.

\section{METHODOLOGY}

The present study examines sediment shoaling in the Blind Pass entrance channel via a series of field investigations, through which a numerical model of circulation was established. Time-series bathymetric surveys were conducted, as well as flow measurements. Bathymetric surveys were conducted roughly quarterly from August 2002 to June 2004. The surveys were conducted with a combination of precision echo sounder for depth and a synchronized Real-Time-Kinematic (RTK) Global Positioning System (GPS) for position. Water level variations were measured to cross-check the tidal influence on the floating platform survey. During the study, the northern side of the inlet became too shallow to survey by boat. Level-and-transit surveys using an electronic total station were conducted there monthly from February 2003 to February 2004. The monthly survey of 9 lines over the northern shoal, extending to roughly $1.5 \mathrm{~m}$ water depth, was designed to capture the infilling rate and pattern over this active shoaling area (Fig. 3). Surveys are referenced to NGVD29, which is roughly $0.15 \mathrm{~m}$ below mean sea level in this area.

Tidal flow patterns through the inlet were measured using an upward-looking acoustic Doppler current profiler (U-ADP) in combination with a side-looking ADP (S-ADP). Therefore, flow patterns both through the water column and across the channel were measured. The flow measurements were conducted at two locations with one near the mouth and one near the bend, each for approximately one month (Fig. 3). In addition, flow velocities were measured simultaneously using two U-ADP placed in the thalwegs near the entrances of Johns Pass and Blind Pass. These data are valuable for examining the interaction of the two inlets and for validating the circulation model. 


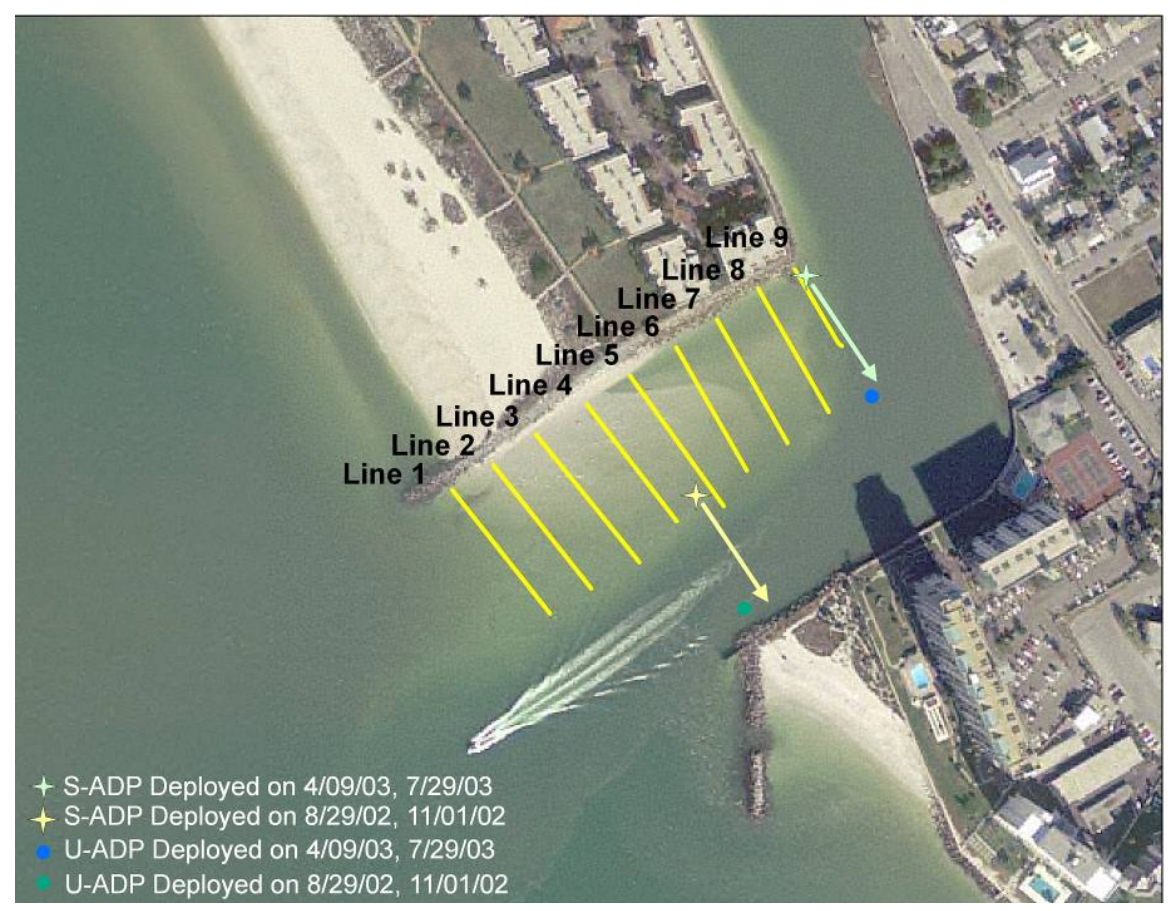

Fig. 3. The north shoal profiles and locations and times of current meter deployments.

A two-dimensional finite-difference model of depth-averaged circulation, the Coastal Modeling System (CMS)-M2D (Buttolph et al. 2006), was set up to simulate tidal-driven flow patterns at both Johns Pass and Blind Pass. A grid consisting of 15x15 m elements and covering approximately the hydraulic circulation extent of the back-bay was generated based on a 2006 bathymetry survey conducted by this study. The model was driven by water-level measurements obtained in January 2001 at Johns Pass and verified with the flow data as described in the above paragraph. The CMS-M2D model has been applied extensively in tidal inlet modeling (e.g., Kraus and Militello 1999; Militello and Kraus 2003; Bounaiuto and Militello 2004). The CMS is a product of the U.S. Army Corps of Engineers’ Coastal Inlets Research Program.

\section{RESULTS AND DISCUSSION}

Sediments along the west-central Florida coast are composed of fine quartz sand with various amounts of, typically larger, shell debris. At present, sediment in the Blind Pass channel varies greatly from the channel thalweg to the shoal area. The surface sediment in the channel thalweg is mostly shell lag with grain size ranging from several $\mathrm{mm}$ to several $\mathrm{cm}$. The mean grain size of sediment along the slope of the main channel averages about $0.35 \mathrm{~mm}$, with a considerable amount of shell debris. The mean grain size of sediment in the shoal area averages about $0.18 \mathrm{~mm}$, predominantly fine quartz sand. Sediments in the shallow area close to the north jetty tend to be coarser, averaging $1.1 \mathrm{~mm}$, with a large amount of shell debris. This variation in sediment grain size is controlled by selective sediment transport by currents and waves. Stronger currents in the channel thalweg produce the coarse lag; and breaking waves along the north jetty are responsible for the coarse sediment there. 
Tidal Flow Patterns

The tide in the study area is mixed diurnal and semi-diurnal. Spring tides, with a range approaching $1 \mathrm{~m}$, tend to be diurnal. A secondary cycle of typically less than $20 \mathrm{~cm}$ in range usually occurs on the rising phase of spring tide (Fig. 4). Neap tides ranging to about $0.5 \mathrm{~m}$ are mostly semi-diurnal. Therefore, although spring tide has greater overall range, the rate of water level change during the rising phase is not greater than the semidiurnal neap tide; however, the rate of the falling phase is greater.

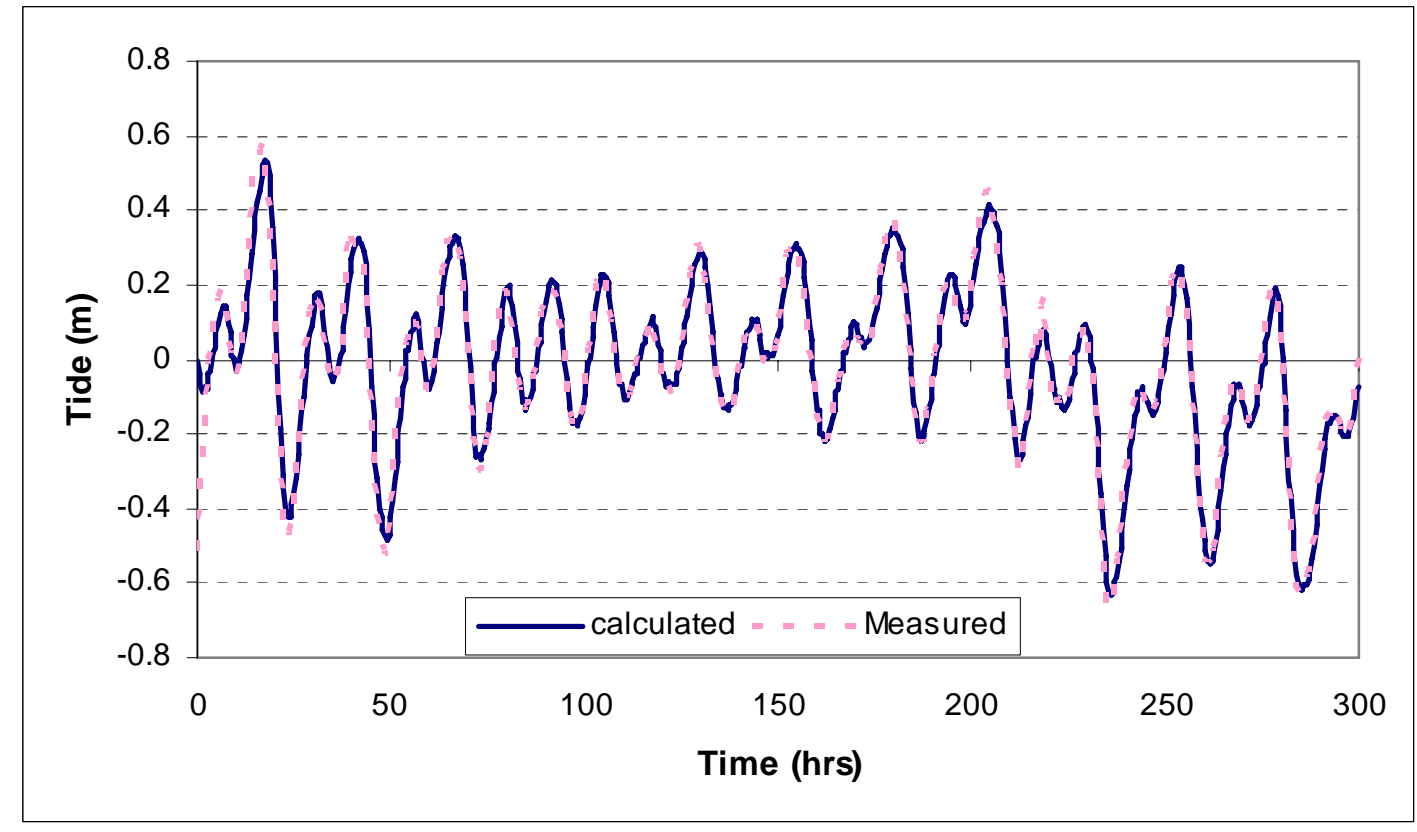

Fig. 4. Measured and calculated tidal water level at Blind Pass, January 12 to 25, 2001.

The measured flow velocity through Blind Pass exhibits the aforementioned tidal waterlevel characteristics (Fig. 5). The peak flood velocity is fairly uniform through time, with the weaker velocity appearing during the transition from the semi-diurnal neap to the diurnal spring tide. The peak ebb velocity shows large variation. The peak ebb velocity during spring tide is almost twice the magnitude of the peak flood velocity during neap tide in the channel thalweg. As discussed in the following, spatial variation patterns of flood and ebb currents across the channel also influence the peak magnitude.

Vertical velocity profiles are uniform throughout the water column from $1 \mathrm{~m}$ above the bed (Fig. 6). Vertical velocity profile measurements were conducted in the channel thalweg. A similar homogeneous trend was demonstrated by nearly all the measurements at the two different channel locations and during the different times (Fig. 3). In addition, overall flow velocity and trends through the channel thalweg, measured in January 2001 shortly after the dredging and in August-November 2002 after significant accumulation on the north shoal, are similar. The similarity indicates that the flow through the channel thalweg along the south side of Blind Pass is not significantly influenced by either the dredging or the shoaling that mainly occur along the north side. 


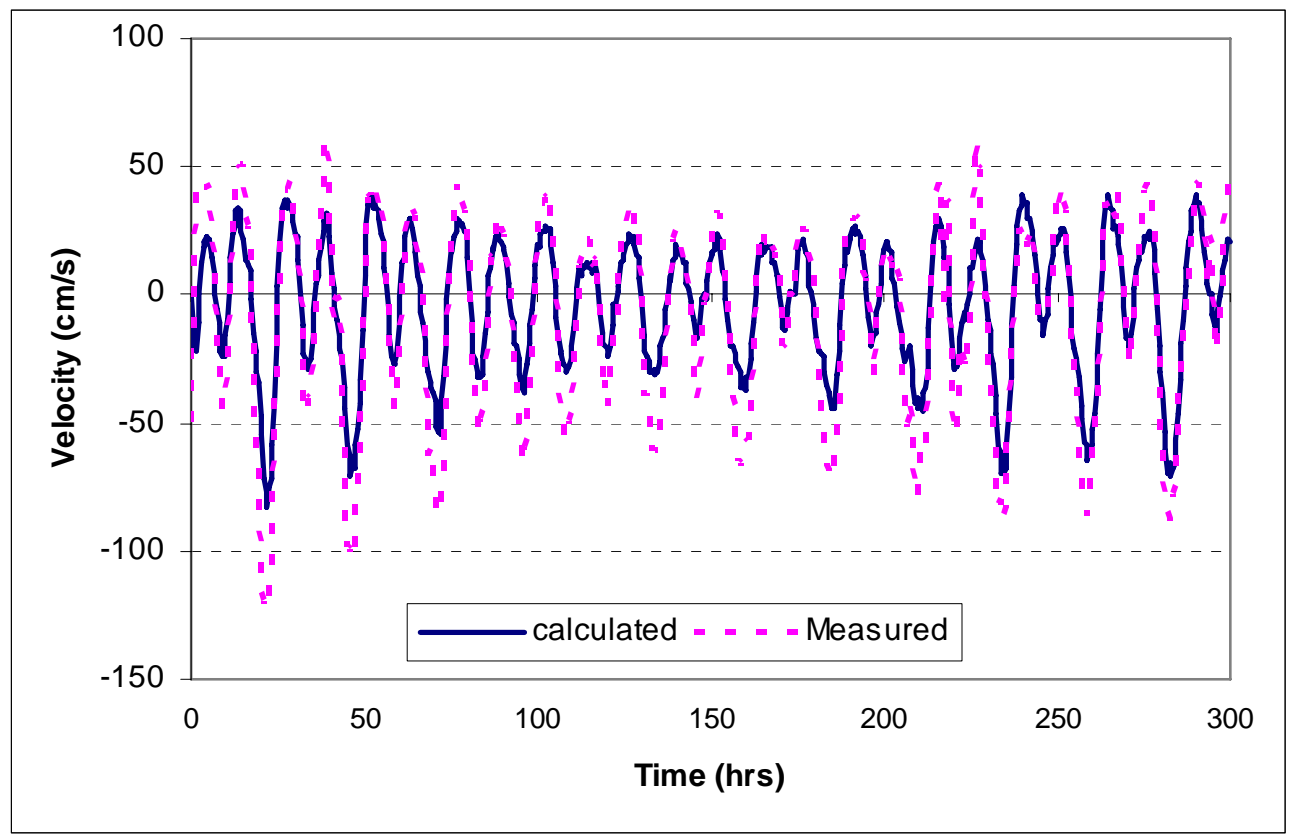

Fig. 5. Measured and calculated tidal flow velocity, January 12 to 25, 2001.

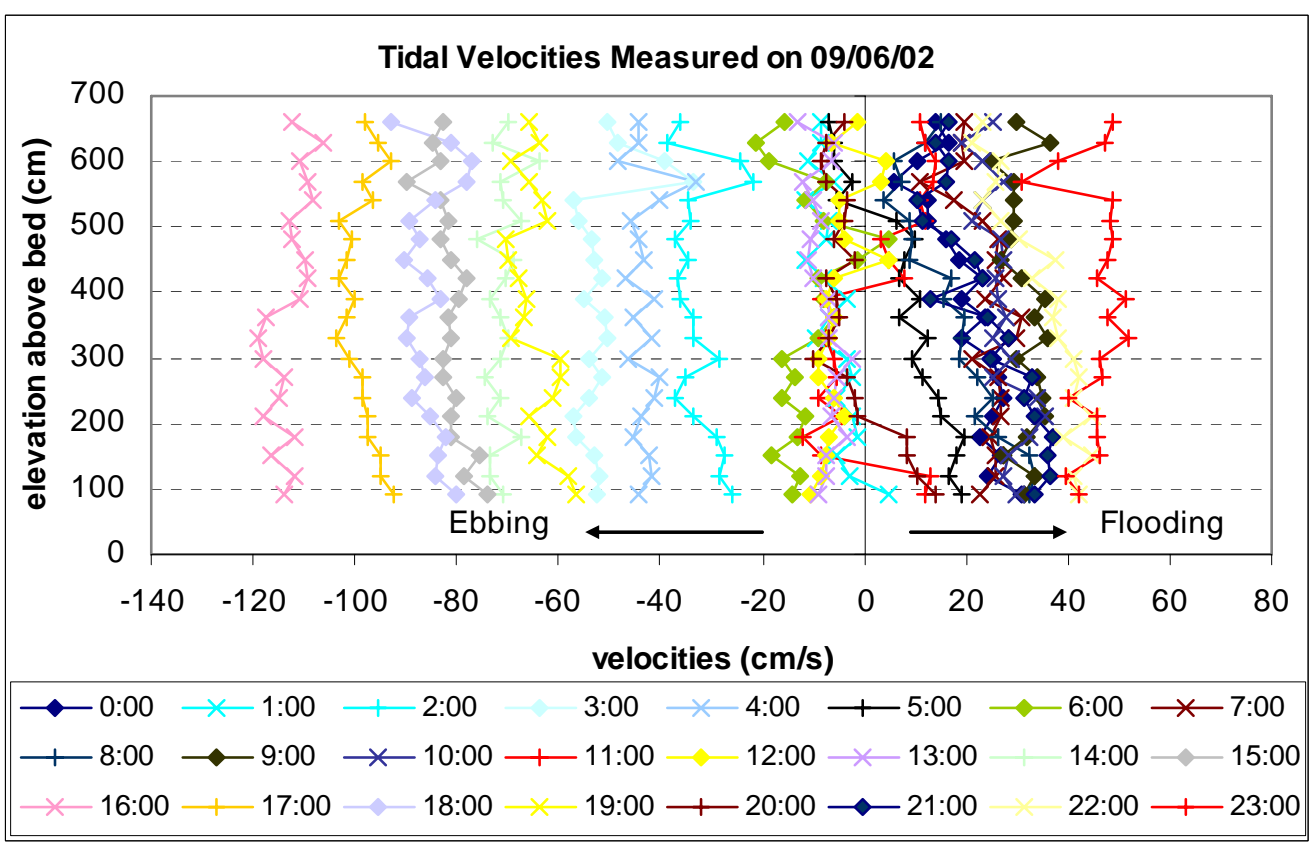

Fig. 6. Typical vertical profiles of current during spring tide.

In contrast to the homogeneous vertical velocity profiles, tidal flow velocity exhibits substantial horizontal spatial variation across Blind Pass channel. In addition, the crosschannel distribution pattern differs between ebb tide and flood tide (Fig. 7). During ebbing tide, flow velocity measured at the channel thalweg is 3 to 4 times greater than that measured over the north shoal. The peak ebb velocity through the channel thalweg approaches $1 \mathrm{~m} / \mathrm{s}$, the equilibrium velocity documented at many inlets (Bruun 1978). During flooding tide, flow velocity is primarily uniform across the channel, peaking at 
about $0.5 \mathrm{~m} / \mathrm{s}$. This distribution of tidal flow velocity across the inlet channel can be attributed to the nearly 90-deg bend. The northern side of the inlet lies in the shadow zone of the ebb current as it turns around the corner. Such a sharp bend is common for migratory inlets, resulting from extension of the updrift barrier island and recession of the downdrift barrier. Therefore, the tidal flow distribution shown in Fig. 7 is likely not unique to the Blind Pass entrance channel.

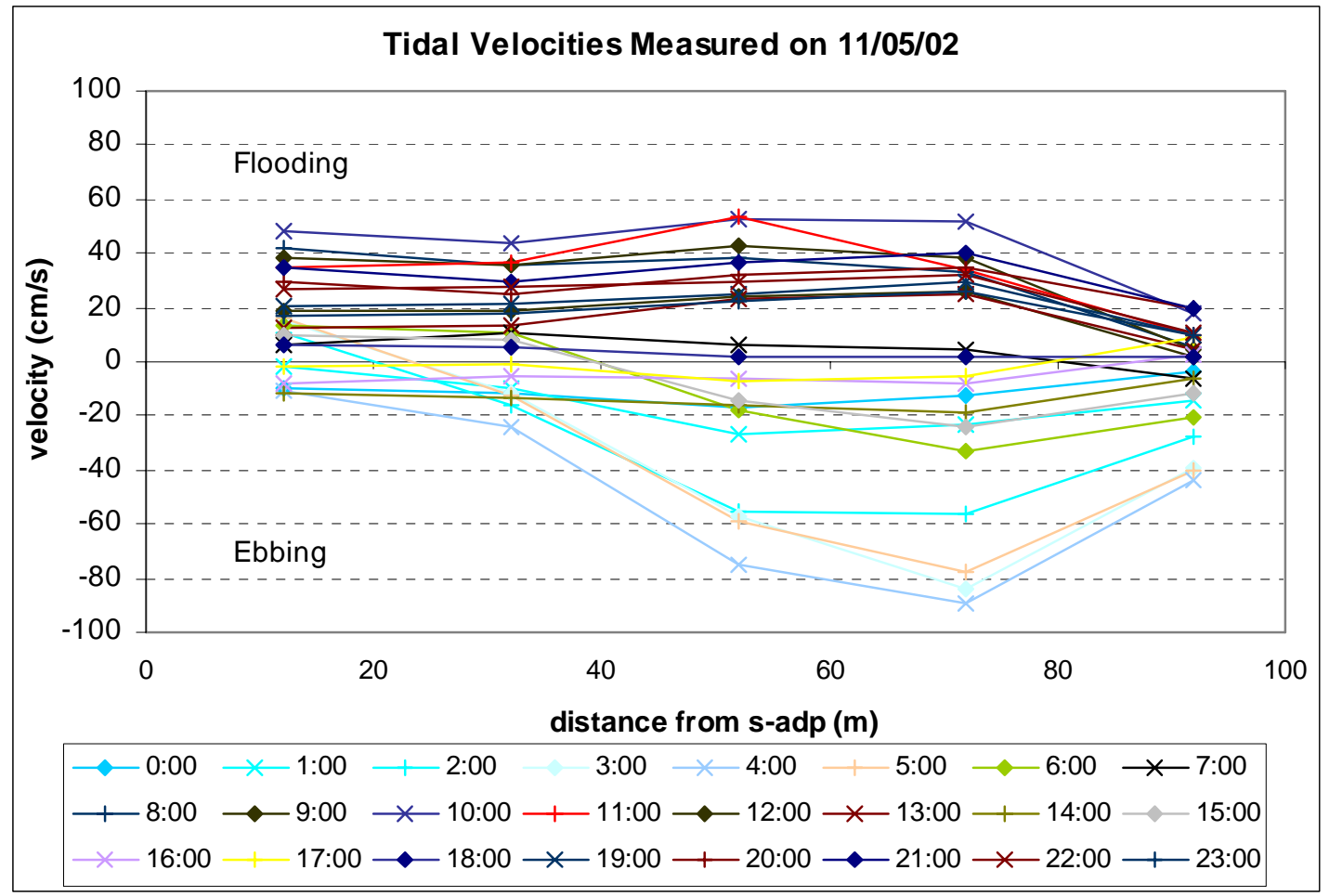

Fig. 7. Example of typical tidal flow distributions across the channel during spring tide.

Given the uniform vertical flow profile and substantial horizontal variation, a depthaveraged circulation model, such as the CMS-M2D, is a suitable and valuable tool to examine the Blind Pass hydrodynamics. The 2-week model run, spanning a spring and neap tide cycle, reproduced the measured water level well (Fig. 4). Measured velocity was also reproduced well, especially during flood (Fig. 5). The under-predicted peak ebb velocity may be related to the fact that a point measurement is compared to an averaged velocity over a $15 \times 15 \mathrm{~m}$ grid. The substantial spatial (horizontal) variation of the ebb flow and the exact location of the flow meter may cause a slight inconsistency. Overall, results from the CMS-M2D represented the observations well over the 2-week period.

The predicted horizontal tidal flow patterns across the inlet channel also compare well with the measured pattern (Figs. 7 and 8 ). The ebb flow tends to hug the south side over the channel thalweg with a peak flow of approximately $1 \mathrm{~m} / \mathrm{s}$, whereas flow over the north shoal is much weaker (Fig. 8A). The flood flow tends to be uniform across the channel, peaking at about $0.5 \mathrm{~m} / \mathrm{s}$ (Fig. 8B). This cross-channel flow pattern is closely related to the shoaling pattern, discussed in the next section. 

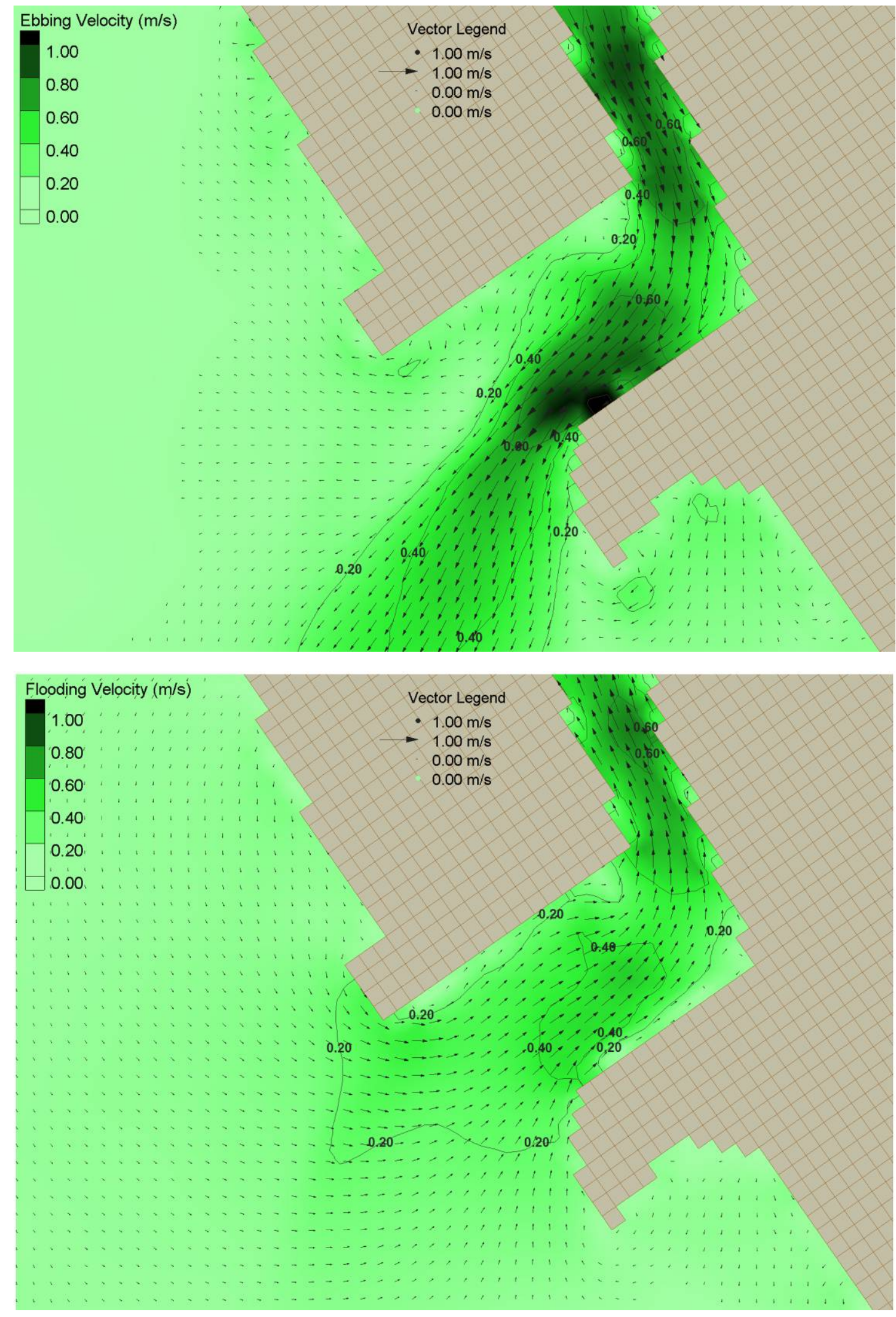
Fig. 8. Examples of modeled ebb (upper panel) and flood (lower panel) flow patterns through Blind Pass.

\section{Shoaling in the Blind Pass Entrance Channel}

Six bathymetric surveys were conducted by this study, in addition to one survey by the USACE, Jacksonville District, in July 2000 shortly after the last channel dredging. Significant shoaling is apparent in the time-series surveys (Fig. 9). Active shoaling occurred in three areas: along the north side, at the eastern corner, and along the south weir jetty. By far, most shoaling occurred along the north jetty. Comparing the July 2000 and August 2002 surveys, net sedimentation of 70,000 $\mathrm{m}^{3}$ occurred during this 2year period, or 35,000 $\mathrm{m}^{3}$ per year. This rate roughly equals the net southward longshore sediment transport rate as obtained by Elko and Wang (2007) from measurements of erosion of the down-drift Upham Beach. This result indicates that Blind Pass has served as a total trap to southward longshore transport.

From August 2002 to August 2003, net sedimentation of 17,000 $\mathrm{m}^{3}$ occurred, as the sum of 25,000 and 2,800 $\mathrm{m}^{3}$ accumulation from August 2002 to December 2002 and from August 2002 to May 2003, respectively, and 11,000 $\mathrm{m}^{3}$ of erosion from May 2003 to August 2003. From August 2003 to June 2004, net accumulation of 26,000 $\mathrm{m}^{3}$ occurred. For both years, net accumulation occurred in the winter months and net erosion in the summer months. This seasonal trend is reflected more clearly in the monthly north-shoal survey, discussed in the following. The reduced amount of sedimentation during 2003 and 2004 is related to sediment backpassing around the corner of the inlet. A beach has developed on the back side of Treasure Island since 2003 and is growing (Fig. 10).

This shoaling pattern relates clearly to the southward net longshore sand transport and tidal flow distribution across the channel. Little shoaling occurs in the channel thalweg due to active flushing by the strong ebb flow. The north side is directly downdrift of the longshore sediment source. The weak ebb flow is not capable of flushing the sand deposited by the longshore transport, whereas the relatively strong flood flow tends to transport the sand deposited near the mouth further into the channel.

Sedimentation on the north shoal was monitored through monthly surveys of nine lines (Fig. 3). Four areas with different patterns of accumulation and erosion in the shoal can be distinguished as the: mouth area (lines 1 and 2), middle area 1 (lines 3 and 4), middle area 2 (lines 5 and 6), and the inner area (lines 7 through 9). From February to August, or the summer of 2003, a considerable amount of scour occurred in the mouth area (Fig. 11A). Little change was observed during the next two months. A tremendous amount of shoaling occurred in the mouth area between October and December of 2003, or at the beginning of the winter season. Scour was measured during the late winter between December 2003 and February 2004. Further into the inlet in middle area 1, little change occurred during the summer (Fig. 11B). A large amount of shoaling occurred at the beginning of winter, followed by further accumulation during late winter. Even further into the inlet at middle area 2, little change was observed during most of 2003 (Fig. 11C). A tremendous amount of shoaling occurred in the late winter. Near the bend of the inlet at line 9, southward progradation of the shoal occurred throughout the year (Fig. 11D). A large amount of shoaling was also observed during late winter. 

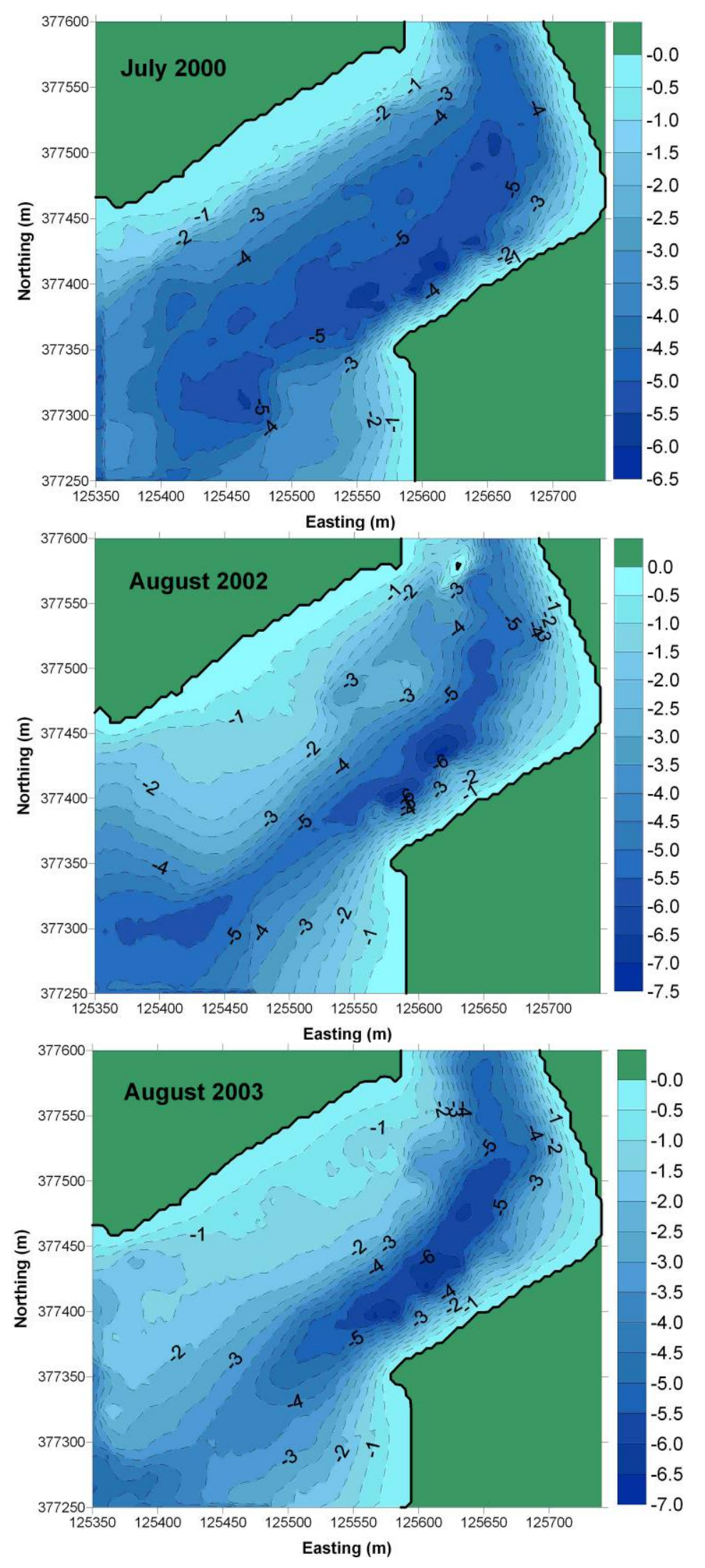

Fig. 9. Shoaling in Blind Pass entrance channel. 


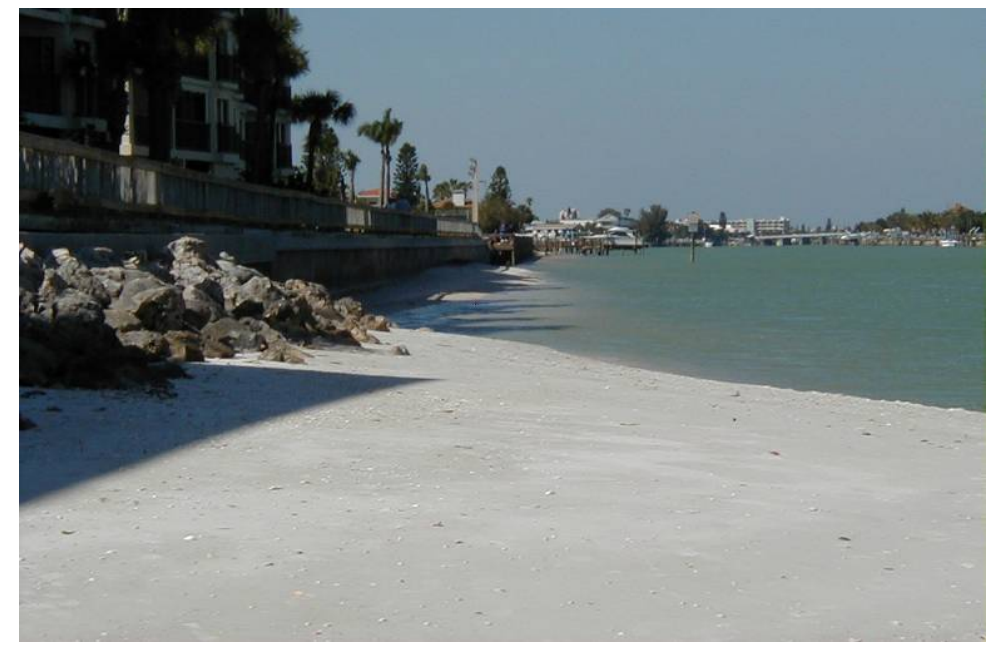

Fig. 10. Beach development along the back side of Treasure Island at Blind Pass, looking north.
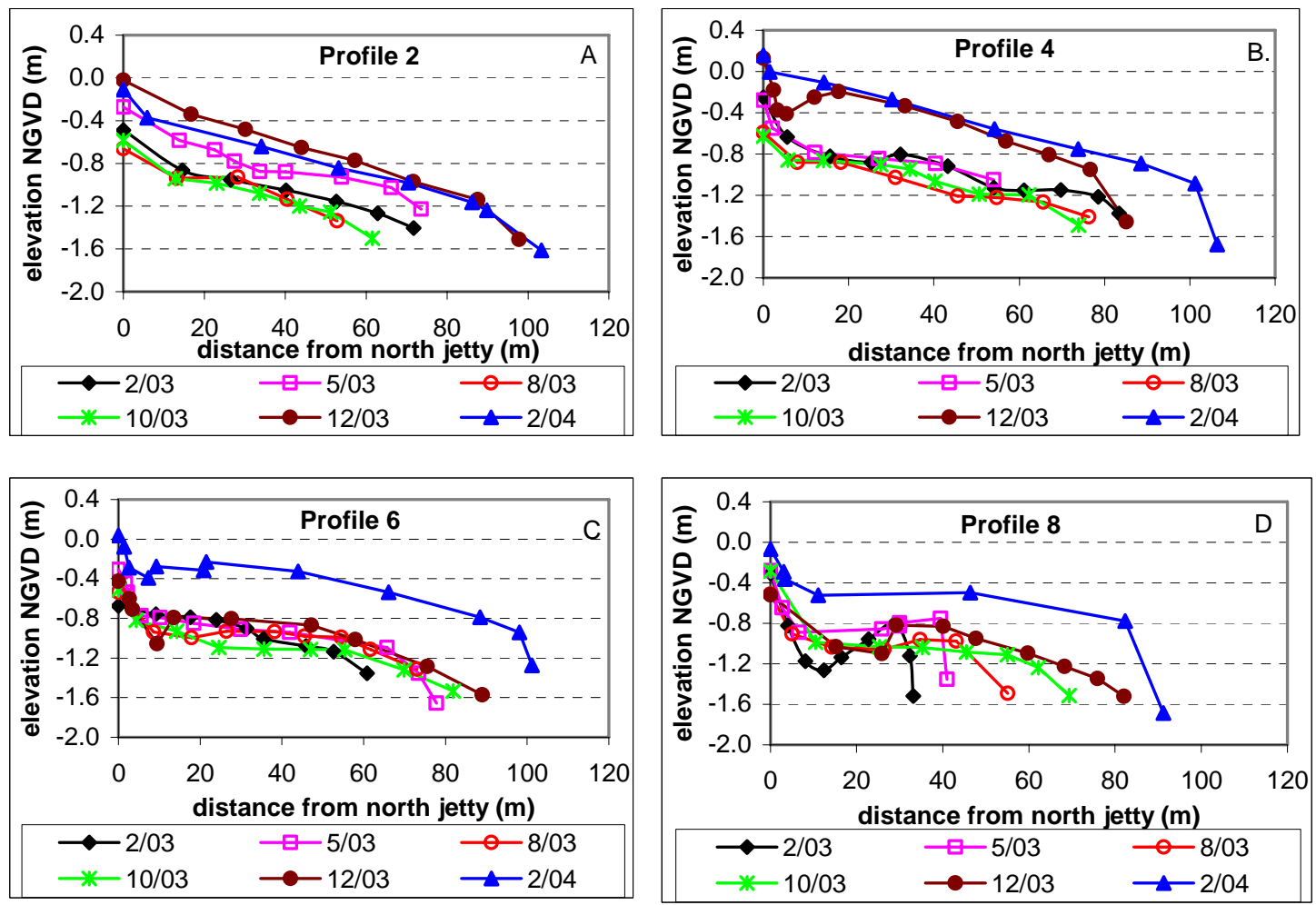

Fig. 11. Time-series of shoaling pattern in Blind Pass entrance channel.

Fig. 11 demonstrates both seasonal and event-driven shoaling and scouring at Blind Pass. During the summer when southwest wind dominates, and little sediment is trapped in the inlet because the sediment supply from the eroding Upham Beach to the south is limited. Furthermore, ebb flushing along the south side is active. As a matter of fact, scour was observed on the north shoal near the inlet entrance, indicating that the sand at the mouth area is being moved further into the inlet, and around the bend. Significant sediment shoaling occurred at the mouth area during the early winter starting in late 
October, especially after the passages of the first several cold fronts. The northerly winds and waves are a major mechanism in driving southward longshore sand transport. The longshore moving sand can deposit readily into the space that was created during the summer season at the mouth area. This body of sand migrates further into the inlet during the winter. Therefore, shoaling in the Blind Pass entrance can be summarized as event-driven (particularly by cold fronts) supply of sediment, followed by redistribution during both low- and high-energy conditions.

The relatively strong flood current over the north shoal is a major mechanism transporting sand further into the inlet and around the bend to the back of Treasure Island. This has effectively limited development of an ebb shoal at Blind Pass. In addition to the flood current, wave breaking over the shallow north shoal and the resulting landward moving surf bore should also contribute significantly to landward sand transport, especially during high waves (Fig. 11). The development and significant growth of the beach on the back side of Treasure Island are results of the landward sand redistribution, in contrast to typical seaward sand transport by ebb flow and development of an ebb shoal.

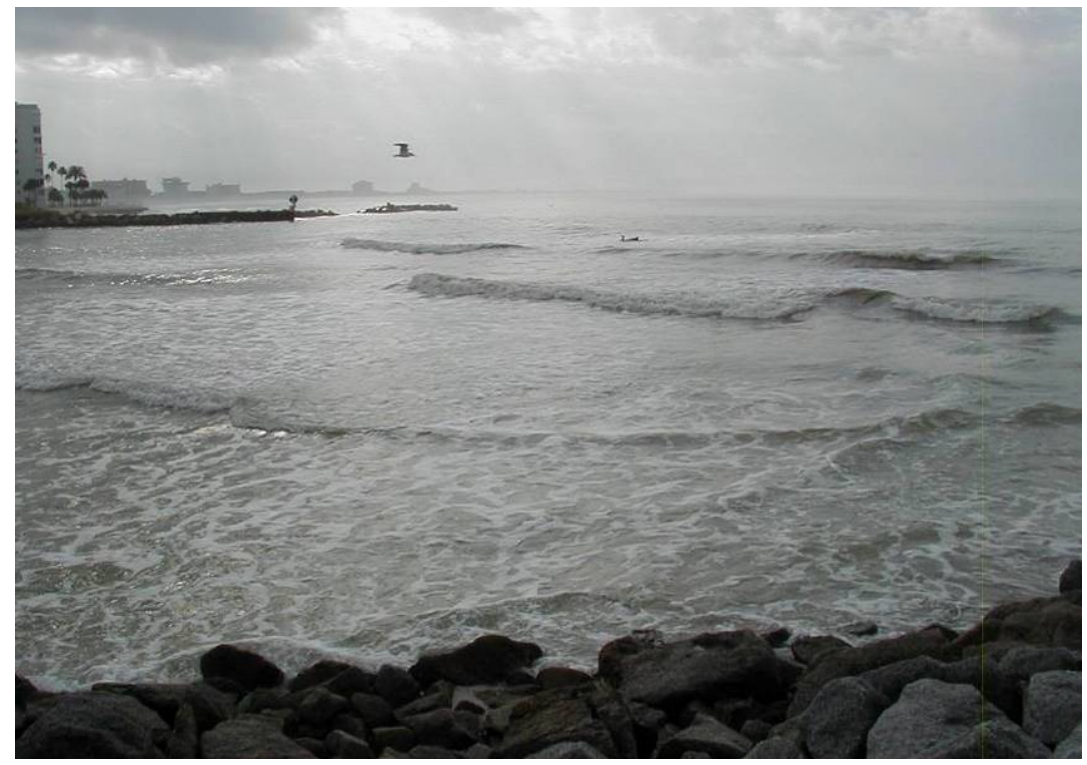

Fig. 11. Wave breaking and surf bores over the north shoal. Looking south.

\section{CONCLUDING DISCUSSION}

Blind Pass represents an example of a stabilized migratory inlet. Both in-situ flow measurements and numerical modeling revealed that ebb flow was approximately twice as strong in the channel thalweg along the downdrift side as compared with the rest of the channel. This strong ebb flow maintains the deep channel there. Flood flow, in contrast, was primarily uniform across the entrance and is stronger than the ebb flow over the northern portion of the inlet. This flow-velocity distribution across the inlet channel, which controls the shoaling patterns, relates to the nearly 90-deg. turn at its entrance to the Gulf of Mexico. The CMS-M2D model reproduced the measured tides and currents accurately. 
Active sand accumulation occurs in the Blind Pass entrance channel, which is maintained by periodic dredging. The shoaling rate in Blind Pass channel approximately equals the net southward longshore transport rate. The inlet is presently serving as a total trap for southward longshore transport. Most of the active sediment shoaling occurs along the north side of the inlet, corresponding to 1) its proximity to the sand source, 2) weak ebb flushing, and 3) stronger flood current. Wave breaking over the shallow north shoal also contributes to the sand re-distribution further landward into the inlet.

Accumulation and erosion patterns at the Blind Pass entrance north shoal demonstrate distinct trends influenced by seasonal wave climate. High-energy waves, especially those driven by passages of cold fronts, play key roles in transporting littoral sand to the inlet channel. Active shoaling in the Blind Pass entrance channel occurs during the winter. This is followed by redistribution of the sand further into the inlet during the summer. The north side of Blind Pass and the growing beach behind Treasure Island are effectively functioning as an impoundment area for sand that is transported southwestward by the longshore current.

\section{ACKNOWLEDGEMENTS}

This study was supported by the Coastal Inlets Research Program (CIRP) at the U.S Army Engineer Research and Development Center, Vicksburg, MS.

\section{REFERENCES}

Bounaiuto, F., and Militello, A. (2004). Coupled circulation, wave, and sediment transport modeling for calculation of morphology change, Shinnecock Inlet, New York. Proc. $8^{\text {th }}$ Int. Estuarine and Coastal Modeling Conf., ASCE, 819-838.

Bruun, P. (1978). Stability of tidal inlets: Theory and engineering. Developments in Geotechnical Engineering, Vol. 23, Elsevier Scientific Publishing Co., NY, 510 p.

Buttolph, A.M., Reed, C.W., Kraus, N.C., Ono, N., Larson, M., Camenen, B., Hanson, H., Wamsley, T., Zundel, A.K. (2006). Two-dimensional depth-averaged circulation model CMS-M2D: Version 3.0, Report 2, sediment transport and morphology change, ERDC/CHL TR-06-9, U.S. Army Engineer Research and Development Center, Vicksburg, MS, 149 pp.

Davis, R.A., and Barnard, P.L. (2000). How anthropogenic factors in the back-barrier area influence tidal inlet stability: examples from the Gulf of Coast of Florida, USA. In K. Pye and J.R.L. Allen (eds.) Coastal and Estuarine Environments: sedimentology, geomorphology, and geoarchaeology. Geological Society, London, Special Publications, 1975, 293-303.

Dean, R.G. (1988). Sediment interaction at modified coastal inlets: Processes and policies. Lecture Notes on Coastal and Estuarine Studies, Vol. 29, 412-439.

Elko, N.A., and Wang P. (2007). Immediate profile and planform evolution of a beach nourishment project with hurricane influences. Coastal Eng., 54(1), 49-66.

Kraus, N.C., and Militello, A. (1999). Hydraulic study of multiple inlet system: East Matagorda Bay, Texas. J. Hydraulic Res., 125(3), 224-232.

Militello, A., and Kraus, N.C. (2003). Numerical simulation of sediment pathways at an idealized inlet and ebb shoal. Proc. Coastal Sediments 03, East Meets West Productions, CD ROM, 14 pp. 